\title{
Male reproduction and environmental and occupational exposures: A review of epidemiologic methods
}

\author{
Anne L. Golden, Ph.D., ${ }^{(1)}$ Jacqueline M. Moline, M.D., M.Sc., ${ }^{(1)} \mathrm{N}$ atan Bar-C hama, M.D. ${ }^{(2,3)}$
}

\section{Golden AL, Moline JM, Bar-Chama N. Male reproduction and environmental and occupational exposures: \\ A review of epidemiologic methods. Salud Publica Mex 1999; 41 suppl 2:S93-S105.}

\begin{abstract}
A bstract
Concerns that chemical exposures in the environment have been detrimental to male sexual development and fertility have been heightened by reports of declining sperm counts over the past 50 years. Marked geographic variation has been found in semen quality and in the incidence of testicular cancer and certain urogenital defects. Debate continues over the existence, magnitude and significance of these trends, and how best to evaluate the hypothesis that in utero and childhood exposures to estrogenic compounds may be to blame. Epidemiologic methods for assessing the impact of hazardous substances on male reproductive health have been develo ped mainly in the area of occupational medicine, and this paper will review the currently recommended methods. These include questionnaires to determine reproductive history and sexual function; reproductive hormone profiles; and semen analyses such as sperm concentration, motility, and morphology. N ew research tools that show significant promise from the fields of clinical reproductive medicine and reproductive toxicology are discussed as possible additions to epidemiologic studies, including assays of sperm function and genetic integrity, and biomarkers of DN A damage. For population-based studies involving occupational groups or communities with environmental exposures, issues related to the cost, validity, precision and utility of these methods must be carefully considered.
\end{abstract}

Golden AL, Moline JM, Bar-Chama N. Reproducción masculina y exposiciones ambientales u ocupacionales: Una revisión de métodos epidemiológicos. Salud Publica Mex 1999;41 supl 2:S93-S105.

\section{Resumen}

Varios artículos publicados informan acerca de una declinación en la concentración de espermatozoides durante los últimos 50 años; lo anterior ha motivado una preocupación creciente en el sentido de que las exposiciones ambientales a diversos químicos actúen en detrimento del desarrollo sexual y de la fertilidad masculina. Se ha observado una marcada variación geográfica en la calidad del semen y en la incidencia del cáncer testicular y diversas malfo rmaciones uro genitales. Persiste un debate acerca de la existencia, magnitud y significado de estos fenómenos y también acerca de la mejor forma para evaluar la hipótesis de que sus causas son las exposiciones in utero a compuestos estrogénicos. En este trabajo se revisan los métodos epidemiológicos recomendables para evaluar el impacto de sustancias peligrosas so bre la salud reproductiva masculina, varios de los cuales provienen del área de la medicina ocupacional. Se incluyen los cuestionarios para determinar la histo ria reproductiva y la función sexual; los perfiles de hormonas reproductivas, y los análisis de semen para medir concentración, morfología y motilidad. También se discute la posibilidad de utilizar para la investigación una serie de nuevas herramientas que provienen de la medicina y de la toxicología reproductivas, entre ellas los ensayos de la función espermática y la integridad genética y los biomarcadores de daño al DN A. Se deben tomar cuidadosamente en consideración los as-

(1) Department of Community and Preventive Medicine, Mount Sinai School of Medicine, N ew York, N ew York, United States of America.

(2) Department of U rology, M ount Sinai School of Medicine, N ew York, N ew York, U nited States of America.

(3) Department of $O$ bstetrics, Gynecology and Reproductive Sciences Mount Sinai School of Medicine, N ew York, N ew York, U nited States of A merica.

Recibed on: July 28, 1998 • Acepted on: March 5, 1999

Reprint requests to:Anne Golden, Ph. D., D epartment of Community and Preventive Medicine.The Mount Sinai School of Medicine. Box 1057. 0 ne Gustave L. Levy Place. N ew York, N ew York, 10029. United States of America. E-mail: anne.golden@ mountsinai.org 
Key words: reproduction; fertility; male; environmental exposure; occupational exposure pectos relativos a la utilidad, validez, precisión y costos de estos métodos para la realización de estudios poblacionales, ya sea que involucren grupos ocupacionalmente expuestos y/o comunidades con exposiciones ambientales.

Palabras clave: reproducción; fecundidad; masculino; exposición a riesgos ambientales; exposición ocupacional
I n 1977, Whorton et al. documented a striking relationship between duration of occupational exposure to the nematocide 1,2-dibromo-3-chloropropane (DPCP) and diminished fertility among men working in a California pesticide factory. ${ }^{1}$ This study sounded the alarm of the potential for chemically-induced injury to male reproductive health. ${ }^{2}$ More recently, threats to male fertility have received greater attention following several reports of a decline in sperm counts over the past 50 years in some $e^{3-10}$ but not all ${ }^{11-13}$ populations, and evidence of marked geographic variation in semen quality. ${ }^{10,14}$ The incidence of testicular cancer has progressively increased in many countries over the last century ${ }^{15}$ and other disorders of the male reproductive tract such as hypospadias and cryptorchidism may have increased in some populations. ${ }^{16,17}$ There is growing concern that occupational factors and environmental chemical exposures, especially in utero and childhood exposures to estrogenic compounds, may be correlated with these observed changes in male reproductive health and fertility. ${ }^{18,19}$

The perception that in recent years an increased emphasis has been placed on determining the frequency and origins of reproductive dysfunction in both females and males is indisputable. ${ }^{20-24}$ In the lay press, the message seems to be that infertility and adverse reproductive events are on the rise ${ }^{25-27}$ and that paternally mediated effects on pregnancy and offspring have been under-appreciated. In reality, the estimated 15 percent prevalence of infertility among married couples (i.e., those who are unable to conceive after 12 months of unprotected intercourse) has not increased significantly over the last four decades. ${ }^{28}$ Late fetal deaths, stillbirths, and major birth defects -the most devastating of adverse reproductive events- occur infrequently, at a rate of less than 5 percent of pregnancies. However, it is now known that a disproportionate number of pregnancies end in spontaneous abortion; it has been estimated that up to 40 percent of all human conceptions are lost before the $28^{\text {th }}$ week of gestation. ${ }^{29,30}$ Rates of subfertility, fetal loss, and adverse outcomes clearly increase with age in women but there is no consistent trend with age of the father. ${ }^{31,32}$
Therefore, the perception that infertility and adverse pregnancy outcomes are increasing may be due in part to changing social trends such as the deferral of childbearing among women in developed countries. Nevertheless, the significance of possible trends of semen quality and other reproductive disorders, ${ }^{33}$ and the influence of occupational and environmental hazards, are active areas of international research. ${ }^{34-37}$

Because of the multifactorial etiologies of adverse pregnancy outcomes and infertility, the proportion of cases that are attributable to the male partner remains unknown. Recent estimates suggest that a "male factor" is present in at least 50 percent of infertile couples and that 30 percent may be caused by a "pure male factor." ${ }^{38,39}$ Furthermore, advances in the availability and success of assisted reproductive technologies, e.g., intracytoplasmic sperm injection (ICSI) for treating male factor infertility, may reduce the chance that a couple will receive a complete infertility work-up to determine the underlying cause. It is unlikely that a primary health care provider or urologist will have the training or the access to information needed to perform appropriate risk assessment for individual patients. ${ }^{24}$ Unfortunately, while many chemical and physical agents found in the workplace and environment are suspected reproductive toxicants, only four exposures (ionizing radiation, lead, the pesticide DPCP, and the disinfectant and fungicide ethylene oxide) are regulated by U.S. occupational safety standards in part due to their reproductive effects.

There are exceptional examples in which the investigation of an occupational or environmental exposure is initiated by some triggering event. These incidents may be exposure-driven (the discovery that workers or residents in a community have been systematically or accidentally exposed to toxic agents) or outcome-driven (an apparent cluster of adverse reproductive events in individuals with recognized exposure to known or suspected reproductive toxicants) or a combination of the two. ${ }^{40}$ The investigations prompted by these "sentinel" events have been the impetus for many recent methodologic developments in reproductive epidemiology and toxicology. Reproductive 
capacity or fertility status per se is assessed most often, but several other disorders or diseases of the reproductive system are also considered as outcomes. For example, testicular cancer and cryptorchidism are strongly correlated with infertility and suggest partially shared etiologies. ${ }^{41}$ Moreover, extrapolation from "ecoepidemiologic" studies ${ }^{19,42}$ of environmental hazards and reproductive problems in other species is currently driving some investigations in human populations. A growing number of reports demonstrate that common, persistent environmental contaminants, including endocrine disrupting chemicals, can influence reproductive function in wildlife and in laboratory animals. These effects have been seen in a range of species from invertebrates to mammals. Some of the most troublesome observations include the severe decline in several terrestrial and aquatic species, ${ }^{43,44}$ demasculinization/feminization of males, ${ }^{43,45,46}$ intersex conditions $^{47}$ and other anomalies like cryptorchidism. ${ }^{48}$ Decades of careless production, use, and disposal of industrial chemical, on the one hand, and national or such as the international initiatives on the other hand, have raised public consciousness and stimulated scientific research regarding potential reproductive effects of environmental and occupational exposures. ${ }^{49}$

Researchers and clinicians interested in male reproductive health and fertility are utilizing increasingly sophisticated methodologies from the fields of toxicology, reproductive medicine, environmental and occupational medicine, and epidemiology. This paper aims to review the methods that have contributed to our current understanding of the impact of hazardous substances on male reproductive capacity. The second objective is to discuss new research tools that may in the future become available and feasible for larger scale epidemiologic studies.

\section{Methods of Assessing Male Reproductive Capacity in Epidemiologic Studies}

Reproductive capacity in the male is analogous to fecundability in the female, i.e., the physiologic capacity of an individual to produce a pregnancy, whether or not that capacity has been fulfilled. Assessment of male reproductive capacity requires the use of several complementary methods ranging from questionnaires that elicit reproductive history to sophisticated tests of semen quality and neuroendocrine function. A full battery of evaluations is most realistic when individuals are motivated by infertility to seek clinical diagnosis and treatment. For population-based studies involving occupational groups or communities with environmental exposures, issues related to the cost, validity, precision and utility of the available methods must be carefully considered..$^{20-22}$

Table I provides a list of measures that are most commonly used and the reproductive functions they assess. The choice of appropriate methodologies to study the effects of reproductive toxicants is predicated by the investigators' understanding of several factors: the nature of the exposed population; the source, the levels and the known routes of exposure; the organ systems in which a toxicant exerts its actions; the hypothesized mechanisms of a toxicant's actions; and the techniques available to assess the effects of toxicants in the relevant organ systems. As shown in table $\mathrm{I}$, the neuroendocrine system, the testes, the accessory sex glands and sexual function are the principal target sites for male reproductive toxicants.

There are several characteristics of the male reproductive system that make it simpler to evaluate than the female system. Male reproductive function is not dependent on a cycle, male germ cells can be obtained

\section{Assessment of Male Reproductive Capacity}

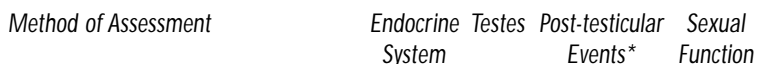

Follicle Stimulating Hormone (FSH) $\quad X$

\begin{tabular}{ll}
\hline Luteinizing Hormone (LH) & $X$ \\
\hline Prolactin & $X$ \\
\hline Testosterone & $X$ \\
\hline Inhibin-B & $X$
\end{tabular}

Sperm density $\quad X$

Sperm morphology and morphometry $X$

Sperm motility (\% motile and velocity) ? X

Sperm viability (vital stain and $\mathrm{HOS}^{\ddagger}$ ) $\mathrm{X}$

\begin{tabular}{ll}
\hline Semen volume & $X$ \\
\hline Semen $\mathrm{pH}$ & $\mathrm{X}$
\end{tabular}

Marker chemicals from accessory

glands $\quad x$

\begin{tabular}{llll}
\hline Sperm function assays & $X$ & $X$ & \\
\hline Sperm chromosome analyses $^{\sharp}$ & $X$ & & \\
\hline N octurnal penile measurements & & & $X$ \\
\hline Personal reproductive history & $X$ & $X$ & $X$
\end{tabular}

* Includes production of seminal plasma components and capacitation of sperm in the epididymis, vas deferens and accessory sex glands

₹ $\mathrm{HOS}=\mathrm{Hyperosmotic} \mathrm{swelling}$

$\S$ Includes acrosome reaction, hemizona assay (HZA) of sperm binding, and sperm penetration assays (SPA)

\# Includes sperm chromatin stability assay (SC SA), Comet assay, and assessment of chromosomal aneuploidy and nuclear microdeletions

\& Includes pubertal development, paternity (pregnancy timing and outcomes), sexual function (erection, ejaculation, orgasm, and libido)

Adapted from Schrader and Kesner (1993) and Schrader (1997) 
by the millions, and the male gonads are more accessible for examination to diagnose or rule out abnormalities. ${ }^{50}$ In humans the total duration of spermatogenesis, the process that results in the formation of spermatozoa from stem cells, is approximately 74 days. Therefore, is it feasible to conduct a prospective study with the expectation that recent exposures can be related to current measures of sperm quantity, quality, fertilizing capacity, and germ cell mutations. On the other hand, studying chronic or historical exposures may be more problematic. With the exception of live births, men may be less likely than women to accurately recall experiences such as time to pregnancy, pregnancy outcomes, or childhood illnesses in their offspring. ${ }^{51,52}$ This needs to be considered when the only source of information on these outcomes is self-report, although the data can be improved by confirmation from existing medical or vital records, or validation by the female partner.

Reproductive history from questionnaires, medical records or vital records

The most common method of assessing fertility status of individuals involves interviewing both the man and his current partner about their reproductive history, including prior marriages and sexual partners. The questionnaire should elicit information about all previous reproductive events, specifically the number of pregnancies, time to pregnancy, interpregnancy intervals, and pregnancy outcomes for each partner. The most common applications of this type of data involve computing "indirect" epidemiological measures of reduced fertility or increased incidence of adverse events in comparison to a standard population or across a range of exposure levels. These measures include the standardized fertility ratio (SFR) which compares the observed number of live births to the expected number of live births based on person-years of observation. The expected number is calculated using the birth rates from an external population, for example, data collected by the National Center for Health Statistics for women of childbearing age in the U.S. Bias can occur if the analysis fails to take into account potential confounding due to age, time period, race, marital status, parity, frequency of intercourse, sterilization and contraceptive use.

More recently, the average time to pregnancy has been used to study the effect of environmental exposures in both male and female populations. ${ }^{53,54}$ In the strictest sense, using delayed time to pregnancy captures the probability of nonconception. In truth, subclinical embryonic losses will contribute "misclassified" delays in time to pregnancy. Women respondents have remarkable long-term recall of the time to conception of recognized (clinical) pregnancies. A recent study found that retrospective data from a questionnaire conducted after a median duration of 14 years were almost identical to data obtained at the time of pregnancy ${ }^{51}$ Male respondents are able to give values for time to pregnancy, but data collected from men tend to be less complete and may be less reliable. . $^{32,52,53}$ Among the limitations of this method are that people who have never achieved a pregnancy are excluded from the analysis. Unacknowledged or mistaken paternity may bias observed associations towards the null. Similarly, recall bias, although it is likely to be nondifferential across exposure groups, will lead to underestimation of associations. Potential confounding by all the factors listed above that can bias the standardized fertility ratio must also be considered. One methodologic modification is to restrict the study population or the analysis to couples who are "at risk" of pregnancy either because they are trying to conceive or are not using effective contraception.

Indirect measures of fertility continue to be widely used as functional parameters that are relatively easy to obtain for large populations. Despite their limitations, they have been shown to correlate with biological markers of reproductive capacity. ${ }^{34,55}$ They can be used to monitor both male-and female-mediated effects, as long as potentially confounding characteristics of both partners can be measured and controlled..$^{32}$ Data from existing medical or vital records and population-based surveys can also be used to explore differences in rates of clinically recognized spontaneous abortion; sentinel phenotypes including congenital defects or cancers in offspring; and temporal or geographic variation in offspring gender ratios. ${ }^{56}$

All research studies of reproductive endpoints should include questions about history of urogenital disorders including infections, injuries or surgeries (see example in Table II). When feasible, a physical examination should be made by a trained clinician, to assess overall male habitus and maturation, including a focused evaluation of the male reproductive system. Routine biochemistry and a complete blood count should be performed to rule out medical conditions associated with fertility problems, e.g., abnormal renal or liver function.

\section{Semen analyses}

More direct assessment of male reproductive capacity can be accomplished by obtaining semen analyses. Standard measurements of sperm concentration, total 
Table II

MEdical history QUeSTIONS fOR USE IN MALE REPROdUCtIVE HEALTH STUDIES

"I have some questions about some medical conditions you may have and medications you may have taken."

MH1. Has a doctor ever told you that you had No Yes If Yes:Year any of the following medical conditions? diagnosed?

\begin{tabular}{lll} 
a. Mumps & 0 & 1 \\
\hline$\quad$ If yes: Did it affect your testicles? & 0 & 1 \\
\hline b. Prostate infection (prostatitis) & 0 & 1 \\
\hline c. Testicle infection (orchitis) & 0 & 1
\end{tabular}

If yes:W hich side?

$1=$ Left $2=$ Right $3=$ Both

d. Epididymis infection (epididymitis) $\quad 0 \quad 1$

If yes: Which side?

$1=$ Left $2=$ Right $3=$ Both

e. Infection of the seminal vesicles (vesiculitis) 0

\begin{tabular}{lll}
\hline $\mathrm{f}$. Blood in your ejaculate/semen & 0 & 1
\end{tabular}

\begin{tabular}{lll}
\hline g. Urinary tract infection & 0 & 1
\end{tabular}

h. Urethritis or discharge from the penis $\quad 0 \quad 1$

i. Chlamydia 001

j. Syphilis 001

k. Gonorrhea

I. Genital herpes

MH2. Have you ever had any of the following No Yes If yes: medical procedures?

Specify

$\begin{array}{lll}\text { a. Vasectomy } & 0 & 1\end{array}$

b. Surgery in the pelvic area (of the prostate,

penis, testes, bladder)

$0 \quad 1$

c. X-rays in the pelvic area for diagnosis

\begin{tabular}{lll} 
or therapy & 0 & 1 \\
\hline d. Testicle biopsy & 0 & 1 \\
\hline e. Hernia repair & 0 & 1
\end{tabular}

MH3. Have you ever had any other urological conditions (problems involving your genital area or urinary tract) or genital injuries for which you needed medical attention?

$\mathrm{No}=0$

Yes $=1$

Don't know $=8$

If yes, specify:
M H4. Have you had a high fever (over $102{ }^{\circ}$ ) during the past 2-3 months?

$\mathrm{No}=0$

Yes $=1$

Don't know $=8$

If yes, specify cause of fever:

M H5. Have you had any viral illness during the past 2-3 months?

$\mathrm{No}=0$

Yes $=1$

Don't know $=8$

If yes, specify:

M H6. Do you take saunas, steambaths, whirlpool baths, or spend time in a hot tube?

\section{$\mathrm{No}=0$}

Yes $=1$

If yes MH 6a. How often in the past 2-3 months did you take saunas, steambaths, whirlpool baths, or use a hot tube? times/per week $=1$

/per month $=2$

MH7. Have you ever taken any of the following Medications/treatments at least 4 consecutive weeks? No Yes $\frac{\text { taking? }}{\text { No Yes }}$

$\begin{array}{lllll}\text { a. Antibiotics } & 0 & 1 & 0 & 1\end{array}$

b. N on-steroidal anti inflammatories

\begin{tabular}{lllll} 
(Motrin,A dvil, Ibuprofen) & 0 & 1 & 0 & 1 \\
\hline c. Estrogen & 0 & 1 & 0 & 1
\end{tabular}

\begin{tabular}{lllll}
\hline d. Testosterone & 0 & 1 & 0 & 1
\end{tabular}

\begin{tabular}{lllll}
\hline e. Radioactive lodine & 0 & 1 & 0 & 1
\end{tabular}

\begin{tabular}{lllll}
\hline f. Steroids (Prednisone, Cortisone) & 0 & 1 & 0 & 1
\end{tabular}

\begin{tabular}{lllll}
\hline g. Antacids, Mylanta, Maalox & 0 & 1 & 0 & 1
\end{tabular}

h. Anti-ulcer medication (Tagamet, Zantac,

$\begin{array}{lllll}\text { Axid, Pepsid, Prilosec) } & 0 & 1 & 0 & 1\end{array}$

i. Anti-hypertensives or blood pressure

$\begin{array}{lllll}\text { medications } & 0 & 1 & 0 & 1\end{array}$

\begin{tabular}{lllll}
\hline$j$. Diuretics & 0 & 1 & 0 & 1
\end{tabular}

\begin{tabular}{lllll}
\hline$k$. Seizure medications & 0 & 1 & 0 & 1
\end{tabular}

I. 0 ther prescription medications currently? $\quad 0 \quad 1$ Specify:

m. 0 ther over the counter medications currently? $\quad 0 \quad 1$ Specify: sperm count, motility and morphology have been the primary research tools for studying the effects of toxicants on the male reproductive system. Epidemiologic studies have successfully utilized semen quality as a marker of fertility ${ }^{34,55}$ although not without problems, e.g., potential selection bias due to low compliance rates, inadvertent inclusion of vasectomized men, and substantial within-individual variability in semen parameters resulting in misclassification based on the static results of a single analysis. ${ }^{57-61}$ Generally accepted normal ranges for the routine semen parameters established using World Health Organization (WHO) methods $^{38}$ and other well established criteria ${ }^{62}$ are shown in Table III. Often in the absence of an unex- 


\section{Table III \\ Semen Analysis Reference Ranges for Normal Values}

\begin{tabular}{ll} 
Volume & $>2.0 \mathrm{ml}$ \\
\hline Appearance & W hitish/G ray-yellow \\
\hline Agglutination (scale 0 to 3) & 0 \\
\hline Liquefaction & W ithin 30 minutes \\
\hline Viscosity (scale 0 to 3) & 0 \\
\hline $\mathrm{pH}$ & 7.2 to 7.8 \\
\hline Sperm density & $>20$ million/ml \\
\hline Total count & $>40$ million \\
\hline Motility (@ $37^{\circ} \mathrm{C}$ ) & $>50 \%$ \\
\hline Progressive Motility & $>50 \%$ \\
\hline W H0 Morphology & $>50 \%$ normal forms \\
\hline Strict Kruger Morphology & $>14 \%$ normal forms \\
\hline Viability (vital stain) & $>75 \%$ alive \\
\hline Round cells & $<1.0$ million/ml \\
\hline W hite blood cells (peroxidase positive) & $<1.0$ million/ml \\
\hline Acrosome reaction assay & D elta $\geq 5:$ Positive
\end{tabular}

Adapted from Bar-Chama and Lamb (1994) and Schrader (1997)

posed control group, the reference point for assessing male reproductive toxicity in exposed populations are these normal values.

Prior to beginning a study, it is incumbent on the investigators to establish a close association with a licensed andrology laboratory. Particularly when research is not the primary function of the laboratory, it will be necessary to ensure that consistent techniques are used, that one technician analyzes all the study samples when feasible, and that specimen aliquots are appropriately prepared and stored for specialized analyses. The study investigators must provide collection jars and storage tubes that are known to be free of any toxicants and have securely fastened labels. Collection instructions should state that the semen sample must be obtained by masturbation after a set period of abstinence (usually 2 to 5 days) and delivered to the laboratory within 1 hour from the time of ejaculation. It is important that each man record the duration of abstinence, time of semen collection, and any information regarding spillage on the label.

Certain semen evaluations must be conducted within one hour after the sample arrives at the andrology laboratory, including recording the temperature, turbidity, color, liquefaction time, volume and $\mathrm{pH}$ of the semen. ${ }^{63,64}$ Sperm counts, preservation of seminal plasma, preparation of slides for morphology and morphometry, and viability assays should also be conducted at this time. If a mobile laboratory is set up for a field study, video recordings can be made for later assessment of motility parameters. Morphologic and morphometric analyses of sperm preserved on slides can be performed at a later time.

Only motile sperm are able to penetrate through cervical mucus, migrate through the female reproductive tract, penetrate the zona of the ova, and achieve fertilization. ${ }^{39}$ In a routine semen analysis, overall quantitative motility is defined as the percentage of sperm that demonstrate any movement. ${ }^{38,39}$ The forward progression of each spermatozoon is qualitatively graded as ' $a$ ' = rapid progressive motility; ' $b$ ' $=$ slow or sluggish progressive motility; ' $c$ ' = non-progressive motility; and ' $\mathrm{d}$ ' = immotility. ${ }^{58}$ Motility and forward progression of spermatozoa analyzed visually by a technician is gradually being replaced by computerassisted sperm analysis systems (CASA). CASA can provide useful information on both the pattern and vigor of motion of sperm cells, including curvilinear velocity, straight-line velocity, linearity, and amplitude of lateral head displacement. ${ }^{64,65}$

Over the past 30 years, several schemes have been presented for the assessment of normal and abnormal appearing sperm. Variations in sperm size and shape are not distinct entities, but rather represent a continuum. This provides a challenge within and especially among laboratories to establish a reliable system for morphological classification. ${ }^{64}$ Insofar as debate continues regarding the most valid methodology for morphology assessment, ${ }^{66}$ and to allow comparison with previous studies of reproductive toxicity which all utilized the WHO semen analysis guidelines, ${ }^{38}$ some labs score all specimens by both the strict Kruger and WHO criteria. New methods have been developed that use transmission and scanning electron microscopy to evaluate the ultrastructural morphology of sperm organelles. ${ }^{67}$ Significant ultrastructural abnormalities have been reported among infertile as compared to fertile men $^{68}$ and in radiation-exposed salvage workers from Chernobyl. ${ }^{69}$ With recent advances in computerized image analysis, methods for objective assessment of sperm head size and shape have been introduced. The andrology laboratory at The National Institute for Occupational Safety and Health (NIOSH) has pioneered a protocol for assessing sperm head morphometry ${ }^{64,70}$ Individual sperm heads are outlined using a digitizing tablet; the software used allows for calculations of area, perimeter, length, width, width/ length ratio, and $4 \pi$ (area) / perimeter $^{2}$ (Pi factor). However, serious impediments remain in achieving agreement among different analysis systems, therefore, comparisons across systems should be avoided. 
The viability and motility of spermatozoa typically reflect seminal plasma quality. ${ }^{64}$ Alterations in sperm viability, as measured by eosin stain exclusion or by hypo-osmotic swelling ${ }^{71}$ or alterations in sperm motility parameters, ${ }^{65}$ suggest a problem with the accessory sex glands. Biochemical analysis of seminal plasma provides insights into glandular function by measuring marker chemicals secreted by each respective gland. For example, the epididymis is represented by glycerylphosphorylcholine (GPC), the seminal vesicles by fructose, and the prostate gland by zinc. Measures of semen $\mathrm{pH}$ and volume provide additional general information on the nature of seminal plasma, reflecting post-testicular effects. A toxicant or its metabolites may act directly on accessory sex glands to alter the quantity or quality of their secretions. Alternatively, the toxicant may enter the seminal plasma and affect the sperm or may be carried to the site of fertilization on the sperm membrane and affect the ova or conceptus. Seminal plasma can be analyzed for the presence of toxicants or their metabolites using atomic absorption spectrophotometry or gas chromotography/mass spectrometry.

As much as any other factor, uncertainty in the results of studies addressing threats to male reproductive health stems from debate about the definition of "normal" reproductive capacity and whether or not expected fluctuations are distinguishable from diminished reproductive capacity resulting from hazardous exposures. ${ }^{72-75}$ Demonstrating a link between an exposure in a human population and an adverse reproductive outcome is rarely straightforward. Methodologic questions regarding intra-individual variation and the precision and reliability of assessment techniques can be addressed to some extent. More than one semen evaluation, usually required by clinicians for a definitive classification of fertility status, ${ }^{39}$ is also desirable although less feasible in epidemiologic investigations. Individual semen samples can be split and replicate measurements made. The mean value from multiple aliquots can be used and intraclass correlations and coefficients of variation can be determined. It is more difficult, however to resolve questions about the validity of routine semen analyses. Which semen parameters are most predictive of fertility? Can threshold levels associated with impaired fertility be defined? Are shifts in sperm quantity and quality within populations related with measurable decreases in normal live births? ${ }^{33,34,55}$ The uncertainties associated with traditional semen parameters has led to the development of assays to assess sperm functioning and genetic integrity which may be more sensitive and specific targets for toxicant actions.

\section{Sperm function assays}

Fertilization requires a series of intricate biochemical events that begins with sperm capacitation, followed by binding to the zona pellucida of the ovum and acrosomal discharge, binding to the oolemma and, finally, penetration into the ooplasm. ${ }^{39,76}$ Abnormalities in any of the biochemical reactions by which sperm access and penetrate the ovum may be a source of infertility. There is considerable interest in determining the utility of including assessment of sperm functioning in epidemiologic studies of reproductive toxicity. ${ }^{50}$ Although a variety of assays for evaluating sperm function have been developed recently, no single test is capable of evaluating all the steps involved in fertilization. ${ }^{39}$ Certain sperm function assays may reflect toxicant effects at more that one site, for example, direct gonadotoxicity affecting spermatogenesis plus post-testicular effects on accessory sex gland secretions. A combination of tests can complement each other in providing a comprehensive evaluation of sperm functions. These include the penetration of sperm through cervical mucus (or viscous fluids simulating cervical mucus), the penetration of sperm into a zona-free hamster egg (sperm penetration assay or SPA), and the binding of sperm to the zona pellucida from a human ovum (hemi-zona assay or HZA). The acrosome reaction has been studied extensively as a predictor of fertilization success because it is a stable parameter of sperm function which, independently of oocyte quality, reflects the ability of the spermatozoa to capacitate. ${ }^{77}$ The acrosome, a membrane-bound organelle covering the anterior two-thirds of the sperm head, contains numerous enzymes whose release is required for penetration of the zona pellucida. It is hypothesized that this release of enzymes is induced by one or more of the zona pellucida glycoproteins. In men with otherwise normal semen analyses, it has been shown that the failure of a significant proportion of sperm to undergo the acrosome reaction when appropriately stimulated is associated with lower in vitro fertilization (IVF) rates. ${ }^{77}$ In addition, the acrosome reaction has a higher predictive value than standard semen analyses, including standard sperm head morphology. ${ }^{77}$ A study by Menkveld et al. found that normal acrosomal morphology was strongly correlated with IVF success, independently of acrosome activity and normal sperm head morphology. ${ }^{78}$

Issues related to the reliability, validity and availability of the sperm function assays and the tests of genetic integrity described below have limited their assimilation into epidemiologic studies..$^{39,50}$ These concerns include the level of expertise needed to run some 
of the more complex assays, the time and expense involved in performing the tests, the difficulties establishing standardization and quality control of the assays, and general doubts about the significance of isolated functional or genetic abnormalities in individual sperm cells.

\section{Tests of genetic integrity or damage}

Epidemiologic studies of large populations have demonstrated increased frequency of congenital anomalies associated with various paternal occupations. ${ }^{79}$ Given the low frequency of even the most common anomalies, such studies require a population base of thousands of pregnancies in order to have a reasonable probability of detecting an increased risk. Numerous case-control studies of childhood cancers have found significant associations with paternal occupations and exposures, ${ }^{80}$ but between-study variation with respect to case populations, control groups, and methods of data collection and analysis makes it difficult to interpret the findings. There has been considerable interest in developing more direct methods for use in epidemiologic studies to detect genetic damage in human germ cells that result from exposure to toxic agents. $^{81}$

Environmental toxins may affect sperm DNA in various capacities, including disruption of the meiotic chromosome segregation (aneuploidy), fragmentation of the DNA, individual genetic mutations, disruption of the DNA structure (chromatin integrity), and production of DNA adducts. Assessing various DNA parameters in human germ cells is important for understanding whether a particular genetic alteration can affect the next generation, and to ascertain the level of toxicant exposures associated with specific germ cell end-points. If abnormalities are found, they may help to explain some of the subfertility and increased risk for spontaneous abortions noted in workers with particular occupational exposures.

The Comet assay detects genetic fragmentation by depicting DNA migrating out of the cell nucleus during electrophoresis. ${ }^{82}$ Cells with undamaged DNA appear as intact heads without tails after specified electrophoresis times. DNA that has been fragmented will contain numerous strand breaks and will therefore migrate further than normal intact DNA. When visualized microscopically, the migrating DNA resembles the tail of a comet. After staining with ethidium bromide, the migrating DNA is quantified by measuring the intensity and extent of the fluorescence pattern. Increasing the duration of electrophoresis may enable detection of extremely low levels of DNA fragmenta- tion. In addition, measuring the fluorescent intensity following DNA migration provides quantitative geometric measurements of the area and density of the dispersion DNA damage. The Comet assay has the significant advantage of being able to assess DNA fragmentation in individual cells.

The Comet assay has been used to measure DNA damage in individual human lymphocytes using relatively low doses of ionizing radiation and chemical genotoxins. ${ }^{82}$ Refinements to the methods are being made to extend its applicability to other environmental exposures and lifestyle factors such as smoking ${ }^{83}$ and other target tissues including sperm cells. ${ }^{8487} \mathrm{An}$ derson et al., ${ }^{87}$ for example, detected DNA fragmentation using the Comet assay with DBCP, two estrogens ( $\beta$-estradiol and the phytoestrogen daidzein) and 1,2epoxybutene (a metabolite of 1,3-butadiene) in a small study of six human semen samples.

Structural or numerical chromosomal abnormalities are relatively frequent in human germ cells and cause serious reproductive problems such as spontaneous abortion and congenital defects. Mikamo et al. ${ }^{88}$ and Martin et al. ${ }^{89}$ found that $1-2 \%$ of human sperm have an abnormal number of chromosomes and approximately $10 \%$ carry structural chromosome aberrations. Aneuploidy, i.e., abnormal chromosome number, can be detected using fluorescence in situ hybridization (FISH) with chromosome-specific DNA probes..$^{90}$ Multiple probes can be employed to evaluate numerous chromosomes in a single cell. ${ }^{91}$ The chromosomes usually evaluated when assessing sperm with FISH are the sex chromosomes as these appear to be most at risk for nondisjunction, suggesting that there is a chromosome-specific variation in nondisjunction frequencies. ${ }^{92}$ FISH has been used to assess factors that may induce sperm aneuploidy in humans such as advanced maternal and paternal age, cancer chemotherapy, and radiation..$^{93-95}$ The techniques show promise for assessing lifestyle factors like tobacco, caffeine, and alcohol ${ }^{96,97}$ as well as environmental exposures including pesticides and heavy metals..$^{98-100}$

Following completion of spermatogenesis, sperm undergo extensive differentiation and maturation. During spermiogenesis DNA is tightly compacted and complexed to protamines. This chromatin structure is important for protection of the DNA and has a significant role in early human post-fertilization events and embryo development. Flow cytometric techniques have been developed to evaluate the chromatin structure of sperm in order to correlate the findings to fertility and as a biomarker of exposure to reproductive toxicants. The sperm chromatin structure assay (SCSA) measures the resistance of sperm DNA to in 
situ denaturation (separating double stranded DNA into single strands) under thermal or chemical stress. ${ }^{101}$ SCSA assesses flow cytogram-generated staining patterns, measuring a shift from green (native DNA) to red (denatured DNA) fluorescence in properly stained sperm chromatin. This shift is seen under conditions of "stress" to the sperm, such as low $\mathrm{pH}$, and has been shown to correlate with toxic chemical exposures, drug exposures and diseases. ${ }^{102-106}$ Limited numbers of studies in both animal (bovine) and human semen have suggested a relationship between sperm chromatin structure and fertility ${ }^{107-109}$ and at least one study found that occupational exposure to lead was associated with decreased sperm chromatin stability. ${ }^{110}$

Unlike the cytogenetic assays (Comet and FISH), individual sperm are not evaluated with SCSA but rather thousands of cells, providing a representation of the whole ejaculate. There is a low variability of SCSA within individuals, with intraclass coefficients ranging between 67 and 90 in healthy volunteers. ${ }^{101}$ Evaluation of semen samples collected in the same individual from two separate months showed highly repeatable results. This assay appears to be sensitive to early stages of chromatin alterations and is a potentially important method to assay for early events of toxicant-induced chromosome damage.

The cytogenetic and chromatin structure assays provide independent assessments of sperm quality that may or may not correlate well with other semen parameters. In infertility clinic populations, sperm density, total count, and morphology have shown low to moderate correlation with SCSA values. ${ }^{101}$ However, in many studies in animals and humans, poor quality sperm chromatin structure was highly indicative of male subfertility. ${ }^{109}$ Therefore, these assays may be of use in subfertile men who otherwise have "normal" semen parameters.

Efforts are also being made to develop biochemical markers of sperm DNA damage. Reactive oxygen species (ROS) are a group of potentially destructive molecules implicated in the oxidative damage of biological structures. These ROS, including the superoxide anion, the hydroxyl radical and hydrogen peroxide, may either be produced endogenously through cellular pathways of the mitochondria and lysosome, or induced exogenously in reaction to environmental assaults. Ultraviolet and X-ray radiation and oxidatively reactive compounds, such as those found in cigarette smoke, alcohol, and air pollution, have all been shown to induce the formation of harmful ROS.111 Over the past decade, concern has been raised after numerous studies reported the reactivity of ROS to DNA nucleotides and suggested the potential for ROS to gener- ate genetic mutations that may evolve to cancer or birth defects if germ cells are damaged. ${ }^{112,113} 8$-Hydroxydeoxyguanosine $(8-\mathrm{OHdG})$ is one of many products of oxidative DNA damage and is currently used to evaluate ROS damage, including the analysis of $8-\mathrm{OHdG}$ levels in the semen. DNA is enzymatically digested to excise damaged nucleosides and then analyzed with high performance liquid chromotography (HPLC) to quantify 8 -OHdG levels. Shen et al. ${ }^{113}$ used this assay to correlate a dramatic increase of 8-OHdG in semen of men exposed to cigarette smoke. In addition to damaging DNA, ROS are also known to oxidize cellular membrane fatty acid components. Sperm cells are especially sensitive to this lipid peroxidation because of the increased density of unsaturated fatty acids needed for sperm membrane fluidity, and the decreased intracellular space available in sperm heads for antioxidant protection. ${ }^{114}$ Oxidatively damaged lipids remain in the plasma membrane and may be assayed through a biochemical technique that converts lipid peroxides into detectable malondialdehyde. ${ }^{115}$ These assays allow analysis and characterization of oxidative stressors that may affect male reproductive ability and may help determine effective preventative antioxidant interventions, if indicated. ${ }^{116}$

DNA adducts are the complexes formed between a toxicant or its metabolites and DNA. The presence of these adducts affects DNA synthesis and repair, and may induce genetic mutations that cause cancer or other adverse outcomes. ${ }^{117}$ A common source of adductgenerating compounds that has been widely studied is polycyclic aromatic hydrocarbons (PAHs). ${ }^{118} \mathrm{PAHs}$ are environmentally ubiquitous compounds formed from the industrial manufacture and combustion of organic compounds found in coal, tars, petroleum oils, and cigarettes. PAHs do not form DNA adducts innately but must first be metabolically activated by cellular P450-dependent monooxygenases. Arene oxides, quinones, diol epoxides and other PAH metabolites have all been discovered to form DNA adducts. Adducts can be detected through ${ }^{32} \mathrm{P}$ radiolabeling, but HPLC seems to be more effective at determining the presence of DNA adducts.

\section{Reproductive hormone profiles}

The profile recommended by NIOSH to evaluate endocrine dysfunction associated with reproductive toxicity consists of serum concentrations of folliclestimulating hormone (FSH), luteinizing hormone (LH), testosterone, and prolactin. Because of the pulsatile secretion of $\mathrm{LH}$, testosterone and to a much lesser extent $\mathrm{FSH}$, as well as the variability in the evaluation of 
reproductive hormones, it is recommended that three blood samples be drawn at set intervals in the early morning, and the results pooled or averaged for clinical assessment. ${ }^{119,120}$ In epidemiologic field studies, however, multiple blood samples are impractical and may decrease participation rates. ${ }^{121}$ Schrader et al. ${ }^{121}$ determined serum concentration of FSH, $\mathrm{LH}$, testosterone and prolactin as part of a longitudinal study of workers. They assessed the reliability of the measurements over time and compared the results from a single sample to the average from three blood samples drawn 20 minutes apart; samples were drawn between 8 a.m. and 8 p.m. on three occasions three months apart. The precision for these hormone measurements was very similar, although there was some decrease in the intraclass correlation coefficient for $\mathrm{LH}$ and prolactin. The measurements from samples drawn 20 minutes apart were highly correlated, and the major sources of variation occurred across individuals and over time (samples drawn three months apart); therefore, multiple measurements at short intervals on the same day do not increase precision. Alternatively, LH and FSH can be measured in urine, providing indices of gonadotropin levels that are relatively unaffected by pulsatile secretion. However, if an exposure can affect hepatic metabolism of sex steroid hormones, ${ }^{122}$ urinary measures of excreted testosterone metabolite (androsterone) or estradiol metabolite (estrone-3-glucuronide) are not recommended. There are currently no assays available to measure prolactin in urine.

Future assessment of reproductive hormones may extend to inhibin, activin and follistatin, polypeptides that are secreted primarily by the gonads and act on the pituitary to increase (activin) or decrease (inhibin and follistatin) FSH synthesis and secretion. Within the gonads, these peptides regulate steroid hormone synthesis and may also directly affect spermatogenesis. Ongoing studies are investigating the utility of serum inhibin-B level as an important marker of Sertoli cell function and in utero developmental toxicity. ${ }^{123,124}$

\section{Sexual function}

Sexual function is attained through the integrated activities of the testes, the accessory sex glands, the endocrine control systems, and the neurological, behavioral, and psychological components of reproduction that are controlled by the central nervous system. ${ }^{64}$ Assessments of libido, erection, ejaculation, and orgasm are difficult to make under normal conditions, therefore, detecting decrements associated with exposure to hazardous agents is very challenging. Questionnaires that require an individual to recall and report his sexual functioning may be confounded by psychological needs to guard a masculine image or to attribute pre-existing problems to occupational or environmental exposures. Therefore, there is ongoing research to develop objective means of evaluating sexual function, for example, monitors that quantify the frequency and quality of nocturnal erections. ${ }^{64}$

\section{Conclusion}

Clearly, initiating an investigation of occupational or environmental male reproductive hazards requires a team that includes urologists, occupational physicians, epidemiologists, andrologists, toxicologists, industrial hygienists, molecular biologists, technicians, and the men themselves as well as their labor union or employer, when applicable. Decisions regarding the study design and evaluations should be guided by input from these experts, characteristics of the population at risk, the relevant exposure(s), and the available resources. It is important that researchers consider the added-value of integrating some of the methods outlined in this paper, including tests of sperm function and genetic damage, into future epidemiologic studies of the impact of environmental and occupational exposures on male reproductive health.

\section{Acknowledgements}

This work was supported in part by grant H75/ ATH282894 from the Agency for Toxic Substances and Disease Registry (ATSDR), Public Health Service, U.S. Department of Health and Human Services. We gratefully acknowledge Sony Ta for his critical review and assistance with the manuscript preparation.

Supported in part by Grant \#1 D43 TW00640 to the Mount Sinai/Queens College International Training Program in Environmental and Occupational Health by the Fogarty International Center of the United States National Institutes of Health.

\section{References}

1. W horton D, Krauss RM, Marshall S, Milby TH. Infertility in male pesticide workers. Lancet 1977;D ecember 17, 1259-1261.

2. Milby TH,W horton D. Epidemiological assessment of occupationally related, chemically induced sperm count suppression. J 0 ccup Med 1980;22: 77-82.

3. Auger J, Kunstmann JM, C zyglik F, Jouannet P. D ecline in sperm quality among fertile men in Paris during the past 20 years. N Engl J Med 1995; 332:281-285. 
4. Bostofte E, Serup J, Rebbe H. Has the fertility of Danish men declined through the years in terms of semen quality? A comparison of semen qualities between 1952 and 1972. Int J Fertil 1983;28:91-95.

5 . Bendvold E. Semen quality in N orwegian men over a 20 -year period. Int J Fertil 1989;34:401-404.

6. Carlson E, Giwercman A, Keiding N, Skakkebaek N E. Evidence for decreasing quality of semen during past 50 years. BMJ 1992;305:609-613.

7. Colborn T, Dumanoski D, Myers JP. 0 ur Stolen Future. N ew York: Dutton Press, 1996.

8. Irvine DS. Falling sperm quality. BMJ 1994;309:476.

9. James W H. Secular trend in reported sperm count. Andrologia 1980; 12:381-388.

10. Swan SH, Elkin EP, Fenster L. Have sperm densities declined? A reanalysis of global trend data. Environ Health Perspect 1997;105:1228-1232.

11. Fisch H, Goluboff ET, O Ison JH, Feldshuh J, Broder SJ, Barad DH. Semen analyses in 1,283 men from the United States over a 25-year period: No decline in quality. Fertil Steril 1996;65:1009-1020.

12. Berling S,W olner-Hanssen P.N 0 evidence of deteriorating semen quality among men in infertile relationships during the last decade: A study of males from Southern Sweden. Human Reproduction 1997;12:1002-1005. 13. Rasmussen PE, Erb K, W estergaard LG, Laursen SB. No evidence for decreasing semen quality in four birth cohorts of 1,055 $D$ anish men born between 1950 and 1970. Fertil Steril 1997;68:1059-1064.

14. Fisch $H$, Ikeguchi EF, Goluboff ET.W orldwide variations in sperm counts. Urology 1996; 48:909-911.

15. Bergstrom R,A dami HO, Mohner M,ZatonskiW, Storm H, Ekbom A et al. Increase in testicular cancer incidence in six European countries. $A$ birth cohort phenomenon.J N atl Cancer Inst 1996; 88:727-733.

16. Giwercman A, C arlsen E, Keiding N, Skakkebaek N E. Evidence for increasing incidence of abnormalities of the human testis:A review. Environ Health Perspect 1993;101 Suppl 2:65-71.

17. Paulozzi LJ, Erickson D, Jackson RJ. Hypospadias trends in two US surveillance systems. Pediatrics1997; 10:831-834.

18. Sharpe RM, Skakkebaek N E. Are oestrogens involved in falling sperm counts and disorders of the male reproductive tract? Lancet 1993; 341:1392-1395.

19. Toppari J, Larsen JC, Christiansen P, G iwercman A, Grandjean P, G uillette $L$ J Jr et al. Male reproductive health and environmental xenoestrogens. Environ Health Perspect 1996;104 Suppl 4:741-803.

20. Savitz DA, Bornschein RL, Amler RW, Bove Fl, Edmonds LD, Hanson JW et al.Assessment of reproductive hazards and birth defects in communities near hazardous chemical sites. I. Birth defects and developmental disorders. Reprod Toxicol 1997;11:223-230.

21. Scialli AR, Swan SH, Amler RW, Baird DD, Eskenazi R, Gist $G$ et al. Assessment of reproductive hazards and birth defects in communities near hazardous chemical sites. II. Female reproductive disorders. Reprod Toxicol 1997:11:231-242.

22.W yrobek AJ, Schrader SM, Perreault SD, Fenster L, Huszar G, Katz DF et al. Assessment of reproductive hazards and birth defects in communities near hazardo us chemical sites. III. G uidelines for field studies of male reproductive disorders. Reprod Toxicol 1997;11:243-259.

23. 0 Ishan AF, Mattison DR, eds. Male-Mediated Developmental Toxicity. $\mathrm{N}$ ew York: Plenum Press, 1994.

24. Paul M, ed. $O$ ccupational and Environmental Reproductive Hazards. A Guide for Clinicians. Baltimore:W illiams and W ilkins, 1993.

25. Lutz D. No conception. The Sciences 1996:36:12-15.

26. Pinchbeck D. D ownward motility. Esquire 1996; January:79-84.

27. W right L. Silent sperm. The N ew Yorker 1996; January 15:42-55.

28.W esthoff $C$. The epidemiology of infertility. In: Kiely M, ed. Reproductive and Perinatal Epidemiology. Boca Ratón FA:CRC Press, 1991:43-61. 29. Shepard TH, Fantel AG, Mirkes PE. D evelopmental toxicology: Prenatal period. In: Paul M, ed. $O$ ccupational and Environmental Reproductive Hazards. A Guide for Clinicians. Baltimore:W illiams and W ilkins, 1993.
30. W ilcox AJ, W einberg CR, O 'C onnor JF, Baird DD, Schlatterer JP, C anfield RE et al. Incidence of early loss of pregnancy. N Engl J Med 1988; 319:189-194.

31. Berkowitz GS, Skovron ML, Lapinski RH, Berkowitz RL. D elayed childbearing and the outcome of pregnancy. N Engl J Med 1990;322:659-664. 32. Joffe $M, L i Z$. Male and female factors in fertility. Am J Epidemiol 1994;140:921-929.

33. Lipshcultz LI. "The debate continues" - the continuing debate over the possible decline in semen quality. (Editorial) Fertil Steril 1996;65:909-911. 34. Bonde JP, H jollund H, Kolstad H, A bell A, Larsen B. Environmental semen studies: Is infertility increased by a decline in sperm count? (Abstract) Proceedings of the International Symposium on Environment, Lifestyle and Fertility; 1997 Dec. 7-10,A arhus, Denmark.

35. Bonde JP, Joffe M, D anscher G,A postoli P, Bisanti L, G iwercman A et al. The European Asclepios study on occupational hazards to male reproductive capability: 0 bjectives, designs and populations. Scand J W ork Environ Health 1999; Supplement 1 (in press).

36. Mbizvo M. Sentinel surveillance on waiting time to pregnancy and semen quality:A multicentre collaborative study. (Abstract) Proceedings of the Hazardous Substances and Male Reproductive Health Conference; 1998 May 14-15, N ew York, N Y, EUA.

37. Swan SH. Is semen quality influenced by environmental factors? W hat can be learned from international collaboration? (A bstract) Proceedings of the Hazardous Substances and Male Reproductive $\mathrm{H}$ ealth Conference; 1998 May 14-15, N ew York, N Y, EUA.

38. W orld Health $O$ rganization.W HO Laboratory Manual for the Examination of Human Sperm and Semen-Cervical Mucus Interaction, Third Edition. C ambridge:The Press Syndicate of the University of $\mathrm{C}$ ambridge, 1992.

39. Bar-C hama N , Lamb DJ. Evaluation of sperm function.W hat is available in the modern andrology laboratory? U rological C linics of $\mathrm{N}$ orth A merica 1994:21:433-446.

40. 0 zonoff $D$,Aschengrau $A$. C ommunity exposures to toxic substances. In: Paul M, ed. $O$ ccupational and Environmental Reproductive Hazards. A Guide for Clinicians. Baltimore:W illiams and W ilkins, 1993:379-392.

41. A kre 0, Lipworth L, C nattingius S, Ekbom A. Risk factor patterns for cryptorchidism, hypospadias and testicular cancer. (Abstract) Proceedings of the Hazardous Substances and Male Reproductive Health Conference; 1998 May 14-15, N ew York, N Y, EUA.

42. Fox GA. Practical causal inference for ecoepidemiologists. J Toxicol Environ Health 1991:33:359-373.

43. Fox GA. Epidemiologic and pathobiological evidence of contaminantinduced alterations in sexual development in free-living wildlife. In: Colborn T, Clement C, (eds).Advances in Modern Environmental Toxicology: Chemically-induced alterations in sexual and functional develo pment. Baltimore:W orld Resources Institute.

44. Fry D M, Toone CK, Speich SM, Peard RJ. Sex ratio skew and breeding pattern of gulls: D emographic and toxicological considerations. Stud Avian Biol 1987:10:26-43..

45. G uillette LJJ, GrossTS, Masson GR, Matter JM, Percival HF,W oodward AR. D evelopmental abnormalities of the gonad and abnormal sex hormone concentrations in juvenile alligators from contaminated and control lakes in Florida. Environ Health Perspect 1994;102:680-688.

46. G uillette LJJ, Pickford D B, Crain DA, Rooney AA, Percival HF. Reduction in penis size and plasma testosterone concentrations in juvenile alligators living in a contaminated environment. G en Comp Endocrinol 1996; 101:32-42.

47. Ellis DV, Pattisina LA.W idespread neogastropod imposex:A biological indicator of global TBT contamination. Mar Pollut Bull 1990;21:248-253. 48. Facemire CF, Gross TS, G uillette LJJ. Reproductive impairment of the Florida panther: N urture or nature. Environ Health Perspect 1995;103 Suppl 4:79-86. 
49. Terraciano G], Lemasters GK, A mler R, eds. Standardized Assessment of Birth Defects and Reproductive Disorders in Environmental Health Field Studies. Atlanta: ATSD R, Public Health Service, U.S. D epartment of Health and Human Services, 1996.

50. Scialli AR, Lemasters GW . Epidemiologic aspects of reproductive toxicology. In:W itorsch RJ, ed. Reproductive Toxicology. Second Edition. N ew York: Raven Press, 1995:241-263.

51.Joffe M,Villard L, Li Z, Plowman R,Vessey M.A time-to-pregnancy questionnaire designed for long-term recall:Validity in 0 xford, England. J Epidemiol Community Health 1995;49:314-349.

52. Fikree FF, Gray RH, Shah F. Can men be trusted? A comparison of pregnancy histories reported by husbands and wives.A m J Epidemiol 1993; 138:237-242.

53. Baird $D D, W$ ilcox $A J, W$ einberg $C R$. Use of time to pregnancy to study environmental exposures. Am J Epidemiol 1986;124:470-480.

54. Joffe M. Feasibility of studying subfertility using retrospective self reports. J Epidemiol Community Health 1989;43:268-274.

55. Fisch $H$, Andrews $H$, Hendricks J, G oluboff ET, $O$ Ison JH, $O$ Isson C A. The relationship of sperm counts to birth rates:A population-based study. J Urol 1997;157:840-843.

56. Davis DL, Gottlieb MB, Stampnitzky JR. Reduced ratio of male to female births in several industrial countries. JAMA 1998;279:1018-1023.

57. Hatch M, Marcus M. 0 ccupational exposures and reproduction. In: Reproductive and Perinatal Epidemiology. Kiely M, ed. Boca Raton: CRC Press, 1993:131-142.

58. Selevan SG. Epidemiology. In: Paul M, ed. $O$ ccupational and Environmental Reproductive Hazards: A G uide for Clinicians. Baltimore:W illiams and W ilkins, 1993:100-110

59. Schrader SM, Turner TW, Breitenstein MJ, Simon SD. Longitudinal study of semen quality of unexposed workers. I. Study overview. Reprod Toxicol 1988:2:183-190

60. Schenker MB, Samuels SJ, Perkins C, Lewis EL, Katz DF, 0 verstreet JW. Prospective surveillance of semen quality in the workplace. J 0 ccup Med 1988;30:336-344.

61. Larsen SB,A bell A, Bonde JP. Selection bias in occupational sperm studies. Am J Epidemiol 1998;147:681-685.

62. Kruger TF, Menkveld R, Stander FS, Lombard CJ,Van der Merwe JP, van Zyl JA et al. Sperm morphologic features as a prognostic factor in in vitro fertilization. Fertil Steril 1986;46:1118-1130.

63. Schrader SM, Kesner JS. Male reproductive toxicology. In: Paul M, ed. 0 ccupational and Environmental Reproductive Hazards. A Guide for Clinicians. Baltimore:W illiams and W ilkins, 1993:3-17.

64. Schrader SM. Male reproductive toxicity. In: Massaro EJ, ed. Handbook of Human Toxicology. Boca Raton, FA: CRC Press, 1997:962-980.

65. Schrader SM, Turner TW, Simon SD. Longitudinal study of semen quality of unexposed workers. Sperm motility characteristics. J Androl 1991; 12:126-131.

66. Morgenthaler A, Fung MY, Harris DH, Powers RD, Alper MM. Sperm morphology and in vitro fertilization outcome:A direct comparison ofW orld Health $O$ rganization and strict criteria methodo logies. Fertil Steril 1995;64: 1177-118.

67. Bartoov B, Eltes F, Langsman J, Snyder M, Fisher J. Ultrastructural studies in morphological assessment of human spermatozoa. Int JAndrol 1982; 5:81-95.

68. Lipitz S, Bartoov B, Rajuan C, Reichart M, Kedem P, Mashiach S et al. Sperm head ultramorphology and chromatin stability of males with unexplained infertility who fail to fertilize normal human ova in vitro.Andrologia 1992;24:261-269.

69. Fischbein A, Zabludovsky N, Eltes F, G rischenko V, Bartoov B. Ultramorphological sperm characteristics in the risk assessment of health effects after radiation exposure among salvage workers in Chernobyl. Environ Health Perspect 1997; 105Suppl 6:1445-1449.
70. Schrader SM, Turner TW, Simon SD. Longitudinal study of semen quality of unexposed workers: Sperm head morphometry. J Androl 1990;11: 32-39.

71. Schrader SM, Platek SM, Zaneveld IJD, Perez-Palaez M, Jeyendra RS. Sperm viability: A comparison of analytical methods. Andrologia 1986:18:530-538.

72. Bigelow PL, Jarrell J,Young MR, Keefe TJ, Love EJ.Association of semen quality and occupational factors: Comparison of case-control analysis and analysis of continuous variables. Fertil Steril 1998;69:11-18.

73. Levine R. Methods for detecting occupational causes of male infertility. Scand J W ork Environ Health 1983:9:371-376.

74. Schenker MB, Samuels SJ, Perkins C, Lewis EL, Katz, DF, 0 verstreet JW. Prospective surveillance of semen quality in the workplace. J 0 ccup Med 1988; 30:336-344.

75. Schrader SM, Turner TW , Breitenstein MJ, Simon SD. Longitudinal study of semen quality of unexposed workers. I. Study overview. Reprod Toxicol 1988;2:183-190.

76. G reen D PL. Mammalian fertilization as a biological machine:A working model for adhesion and fusion of sperm and oocyte. Hum Reprod 1992:44:186.

77. C alvo L, D ennison-Lagos L, Banks SM, D orfmann A, Thorsell L, Bustillo $M$ et al.Acrosome reaction inducibility predicts fertilization success at in vitro fertilization. Hum Reprod 1994:9:1880-1886.

78. Menkveld R, Rhemrev JP, Franken DR, Vermeiden JP, Kruger TF. Acrosomal morphology as a novel criterion for male fertility diagnosis: Relation with acrosin activity, morphology (strict criteria), and fertilization in vitro. Fertil Steril 1996;65:637-644.

79. 0 Ishan AF, Schnitzer PG. Paternal occupation and birth defects. In: 0 Ishan AF, Mattison DR, ed. Male-Mediated Developmental Toxicity, N ew York: Plenum Press, 1994:153-167.

80. Buckley J. Male-Mediated D evelopmental Toxicity: Paternal exposures and childhood cancer. In: 0 Ishan AF, Mattison DR, ed. Male-Mediated Developmental Toxicity, N ew York: Plenum Press, 1994:169-175.

81. Schrader SM. Data gaps and new methodologies in the assessment of male fecundity in occupational field studies. Scand JW ork Environ $\mathrm{H}$ ealth 1992:18 Suppl 2:30-32.

82. Singh N P, MCC oy MT, Tice RR, Schneider EL. A simple technique for quantization of low levels of DNA damage in individual cells. Exper Cell Res 1988;175:184-191.

83. Betti C, D avini T, Giannessi L, Loprieno N , Barale R. Comparative studies by comet test and SCE analysis in human lymphocytes from 200 healthy people. Mutat Res 1995;343:201-207.

84. Hughes CM, Lewis SE, McKelvey-Martin VJ, Thompson W. A comparison of baseline and induced DNA damage in human spermatozoa from fertile and infertile men using a modified comet assay. Mol Human Reprod 1996:2:613-619.

85. Anderson D, D obrzynka MM, Jackson LI,Yu TW, Brinkworth MH. Somatic and germ cell effects in rats and mice after treatment with 1,3butadiene and its metabolites 1,2-epoxybutene and 1,2,3,4-diepoxybutane. Mutat Res 1997;391:233-242.

86. Brinkworth $M H$, Anderson D, Hughes JA, Jackson LI,T ian-W ei Y, N ieschlag E. Genetic effects of 1,3-butadiene on the mouse testis. Mutat Res 1998;397:67-75.

87. Anderson D, D obrzynska MM, Tian-W ei Y, G andini L, C ordelli E, Spano M. DN A integrity in human sperm. Teratog Carcinog Mutagen 1997;17: 97-102.

88. Mikamo K, Kamiguchi Y,Tateno H.The interspecif in vitro fertilization system to measure human sperm chromosomal damage. Prog Clin Biol Res 1991; 372:531-542.

89. Martin RH, Ko E, Rademaker A. Distribution of aneuploidy in human gametes: Comparison between human sperm and oocytes.Am J Med Genet $1991 ; 39: 321-331$ 
90. Martin RH, Spriggs E, Rademaker AW. Multicolour fluorescence in situ hybridization analysis of aneuploidy and diploidy frequencies in 225,846 sperm from ten normal men. Biol Reprod 1996; 54:394-398.

91. Martini E, Flaherty SP, Swann NJ, Payne D, Matthews CD. Analysis of unfertilized oocytes subjected to intracytoplasmic sperm injection using two rounds of fluorescence in-situ hybridization and probes to five chromosomes. Hum Reprod 1997;12:2011-2018.

92.W yrobek AJ, Robbins W A, Mehraien Y, Pinkel D. Weier HU. Detection of sex chromosomal aneuploidies $X-X, Y-Y$, and $X-Y$ in human sperm using two-chromosome fluorescence in situ hybridization.Am J Med Genet 1994; 53:1-7.

93. Kinakin B, Rademaker A, Martin R. Paternal age effect ofYY aneuploidy in human sperm, as assessed by fluorescence in situ hybridization. Cytogenet Cell Genet 1997;78:116-119.

94. Martin RH, Spriggs E, Ko E, Rademaker AW. The relationship between paternal age, sex ratios, and aneuploidy frequencies in human sperm, as assessed by multicolor FISH.Am J Med Genet 1995;57:1393-1399.

95. Robbins W A, Meistrich ML, Cassel MJ, Moore D II,W eier H-U, Hagemeister $\mathrm{FB}$, et al. Chemotherapy induces transient sex chromosomal and autosomal aneuploidy in human sperm. $N$ at $G$ enet 1997;16:74-78.

96. Robbins WA, Vine MF, Truong KY, Everson RB. Use of fluorescence in situ hybridization (FISH) to assess the effects of smoking, caffeine and alcohol on aneuploidy load in healthy men. Environ Mol Mutagen 1997; 30:175-183.

97.W yrobek AJ, Rubes J, C assel M, Moore D, Perrault S, SlottV et al. Smokers produce more aneuploid sperm than non-smokers.Am J Hum Genet 1995:57:A737.

98. Ribas G , Frenzilli G, Barale R, Marcos R. Herbicide-induced D N A damage in human lymphocytes evaluated by the single cell gel electrophoresis (SC GE) assay. Mutat Res 1995;344:41-54.

99. Marchetti F, Lowe X, Moore DH II, Bishop J, W yrobek AJ. Paternally inheritied chromosomal structure aberrations detected in mouse firstcleaving zygote metaphases by multicolour fluorescence in situ hybridization painting. Chromosome Res 1996;4:604-613.

100. Rupa DS, Schuler M, Eastmond DA. Detection of hyperploidy and breakage affecting the 1cen-1q12 region of cultured interphase human lymphocytes treated with various genotoxic agents. Environ Mol Mutagen 1997;29:161-167

101. Evenson DP, Jost LK, Baer RK, Turner TW, Schrader SM. Individuality of $D N A$ denaturation patterns in human sperm as measured by the sperm chromatin structure assay. Reprod Toxicol 1991;5:115-125.

102. Evenson DP. Flow cytometric analysis of male germ cell quality. In: C rissman H , D arzynkiewicz D, eds. Methods in cell biology. San D iego, CA: Academic Press, 1990;vol 18:401-410.

103. Evenson DP, Baer RK, Jost LK. Long term effects of triethylene-melamine exposure on mouse testis cells and sperm chromatin structure assayed by flow cytometry. Environ Mol Mutagen 1989;14:79-89.

104. Evenson DP, Baer RK, Jost LK, Gesch RW. Toxicity of thiotepa on mouse spermatogenesis as determined by dual-parameter flow cytometry.Toxicol Appl Pharmacol 1986;82:151-163.

105. Evenson D P,Arlin Z, W elt S, Claps ML, Melamed MR. Male reproductive capacity may recover following drug treatment with the L-10 protocol for acute lymphocytic leukemia (ALL). C ancer 1984;53:30-36.
106. Evenson D P, Balachey BE, Jost LK, Baer RK. Male germ cell analysis by flow cytometry: Effects of cancer, chemotherapy and other factors on testicular function and sperm chromatin structure. In:Andreeff MA, ed. Proceedings of the Conference on Clinical Cytometry. N ew York: N ew York Academy of Science: 1986:350-367.

107. Ballachey BE, H ohenboken W D, Evenson D P. H eterogeneity of sperm nuclear chromatin structure and its relationship to fertility of bulls. Biol Reprod 1987;36:915-925.

108. Ballachey BE, Evenson D P, Saacke RG. The sperm chromatin structure assay: Relationship with alternate tests of semen quality and heterospermic performance of bulls. J Androl 1988;9:109-115.

109. Evenson D P, D arzynkiewicz Z, Melamed MR. Relations of mammalian sperm chromatin heterogeneity to fertility. Science 1980;240:1131-1133. 110.W ildt K, Eliasson R, Berlin M. Effects of occupational exposure to lead on sperm and semen. In: Clarkson JW, N ordberg G F, Sager PR, eds. Reproductive and developmental toxicity of metals. N ew York: Plenum Press, 1983:279-300

111. Moller P,W allin H, Knudsen L. 0 xidative stress associated with exercise, psychological stress and lifestyle factors. Chemico-Biological Interactions 1996;102:17-36.

112. Fraga C, Motchnik P, Shigenaga M, H elbock H, Jacob R,A mes B.Ascorbic acid protects against endogenous oxidative DNA damage in human sperm. Proc. N atl A cad Sci USA 1991;88:11003-11006.

113. Shen HM, Chia SE, N i ZY, N ew AL, Lee BL, O ng CN . D etection of oxidative DNA damage in human sperm and the association with cigarette smoking. Reproductive Technology 1997;11:675-680.

114. Aitken RJ. A free radical theory of male infertility. Reprod Fert Dev 1994;6:19-24

115. Aitken RJ, Harkiss D, Buckingham DW. A nalysis of lipid peroxidation mechanisms in human spermatozoa. Mol Reprod Dev 1993;35:302-315.

116. Geva E, Bartoov B, Zabludovsky N , Lessing JB, Lerner-G eva L,A mit A. The effect of antioxidant treatment on human spermatozoa and fertilization rate in an in vitro fertilization program. Fertil Steril 1996;66:430-434. 117. Santella RM. D N A damage as an intermediate biomarker in intervention studies. Proc Soc Exp Biol Med 1997;216:166-171.

118.A ngerer J, Mannschreck, G ndel J. Biological monitoring and biochemical effect monitoring of exposure to polycyclic aromatic hydrocarbons. Int Arch $O$ ccup Environ Health 1997;70:365-377.

119. Santen RJ, Bardin CW . Episodic luteinizing hormone secretion in man: pulse analysis, clinical interpretation, physiologic mechanisms. J C lin Invest 1973:52:2617-2628.

120. Sokol RZ. Endocrine evaluations in the assessment of male reproductive hazards. Reprod Toxicol 1988;2:217-222.

121. Schrader SM, Turner TW, Breitenstein MJ, Simon SD. Measuring male reproductive hormones for occupational field studies.J 0 ccup Med 1993; 35: 574-576.

122. A postoli P, Romeo L, Peroni E, Ferioli A, Ferrari S, Pasini F, Aprili F. Steroid hormone sulphation in lead workers. Br J Ind Med 1989;46:204208.

123. Halvorson LM, D eC herney AH. Inhibin, activin, and follistatin in reproductive medicine. Fertil Steril 1996; 65:459-469.

124. Jensen TK, Andersson A-M, H jollund N HI et al. Inhibin-B as a serum marker of spermatogenesis: $C$ orrelation to differences in sperm concentration and follicle-stimulating hormone levels.A study of $349 \mathrm{D}$ anish men. J Clin Endocrinol Metab 1997;82:4059-4063. 